\title{
NATURAL ENEMIES OF THE GALL-MAKER Eugeniamyia dispar (DIPTERA, CECIDOMYIIDAE): PREDATORY ANTS AND PARASITOIDS
}

\author{
MENDONÇA, M. de S., Jr. ${ }^{1,2}$ and ROMANOWSKI, H. P. ${ }^{1}$ \\ ${ }^{1} \mathrm{CPG}$ - Biologia Animal, Instituto de Biociências, UFRGS, Av. Paulo Gama, s/nọ, \\ CEP 90040-060, Porto Alegre, RS, Brazil \\ ${ }^{2}$ Department of Biology, Imperial College at Silwood Park, Ascot, \\ Berkshire, SL7 PY5, UK \\ Correspondence to: Milton de S. Mendonça-Jr., Departamento de Zoologia, CPG - Biologia Animal, \\ Instituto de Biociências, UFRGS, Av. Bento Gonçalves, 9500, Prédio 43435, Bloco IV, \\ CEP 91501-970, Porto Alegre, RS, Brazil, e-mail: milton_mendonca@uol.com.br \\ Received March 29, 2001 - Accepted May 10, 2001 - Distributed May 31, 2002
}

\begin{abstract}
Natural enemies of the gall maker Eugeniamyia dispar (Diptera: Cecidomyiidae) were studied on the urban area of Porto Alegre, RS, Brazil from October 1993 to March 1996. Galls and associated arthropods were followed weekly in the field on individual host plants (Eugenia uniflora, Myrtaceae) and also in the laboratory. Three species of ants attacked the galls, the most common being Pseudomyrmex sp. A proportion of galls was parasitised by Rileya sp. (Eurytomidae). The adults of this solitary ectoparasitoid were also attacked by the ants and fell prey to spider webs.
\end{abstract}

Key words: Eurytomidae, Formicidae, gall, Myrtaceae, parasitoid, predation, Rileya, Pheidole.

\section{RESUMO}

\section{Inimigos naturais do galhador Eugeniamyia dispar (Diptera, Cecidomyiidae):} formigas predadoras e parasitóides

Inimigos naturais do galhador Eugeniamyia dispar (Diptera: Cecidomyiidae) foram estudados na área urbana de Porto Alegre, RS, Brasil, entre outubro de 1993 e março de 1996. Galhas e artrópodos associados a estas foram acompanhados no campo sobre as plantas hospedeiras (Eugenia uniflora, Myrtaceae) e também em laboratório. Três espécies de formiga foram encontradas atacando as galhas, sendo a mais comum Pseudomyrmex sp. Uma proporção considerável das galhas foi parasitada por Rileya sp. (Eurytomidae). Os adultos desse ectoparasitóide solitário também foram atacados pela espécie mais comum de formiga e caíram presas de teias de aranha próximas.

Palavras-chave: Eurytomidae, Formicidae, galhas entomógenas, Myrtaceae, parasitóide, predação, Rileya, Pheidole.

\section{INTRODUCTION}

Ever since Darwin (1859) natural enemies are considered to be of capital importance in the ecology and evolution of all organisms. Frequently, population dynamics studies of herbivore insects indicate natural enemies as regulating factors (Price, 1984). Whatever their impact on their hosts, insect herbivore natural enemies, whether true predators or parasitoids, occur in large numbers of species (Strong et al., 1984). Recently, Cornell \& Hawkins (1995) provided an analysis of sources of mortality in various insect populations, with an emerging pattern of natural enemies as the main cause of death in immature stages.

Gall-maker parasitoids and inquilines form large communities at least on some groups (e.g. Cynipidae, Askew, 1980). In fact, when rearing 
galls, one usually obtains large numbers of parasites rather than the gall-makers themselves (Mani, 1964). Mortality due to parasitoids (and inquilines) in gallmaker Cecidomyiidae is commonly high: about $50 \%$ or higher (Hawkins, 1988 and references therein). Natural enemies may exert important evolutionary pressure on gall-makers, for example in the shift of host plant species attacked (Brown et al., 1995), but may or may not for gall traits such as shape and thickness (Waring \& Price, 1989, but see Weis \& Abrahamson, 1986). There is still much debate about whether galls may provide protection against natural enemies, especially parasitoids, but also other herbivores (see Schultz, 1992) and/or serve different purposes (Price et al., 1987; Price \& Pschorn-Walcher, 1988; Hawkins, 1988; Hartley \& Lawton, 1992).

The midge Eugeniamyia dispar Maia et al. (1996) induces its galls on new leaves of the Neotropical shrub Eugenia uniflora (Myrtaceae). The egg are placed on the plant (up to 33 per leaf), the first instar larva hatches and starts the induction process, thereafter becoming covered by plant tissues (Mendonça, 1996). The gall develops into a white round spongy structure, caused by the hypertrophy of the plant tissues and the loss of chlorophyll. The last larval instar leaves the gall and drops to the soil to pupate. The adult emerges, probably mating close to the emergence sites, and flies up to the plant to oviposit (Mendonça \& Romanowski, 2002). The whole life-cycle takes about two weeks and the insect is multivoltine, being found from late August up until the following June. This paper describes the attack of parasitoids and predatory ants found to be natural enemies of Eugeniamyia dispar during a two-year study of midge populations. Quantitative analysis of the mortality inflicted by the ants and aggregation of adult parasitoids in relation to host density will be treated in future papers.

\section{MATERIALS AND METHODS}

The fate of the galls was followed on Eugenia uniflora plants, sampled weekly from September to May and fortnightly from June to August (winter). Observations were carried out from October 1993 to September 1995 on two sites at the urban area

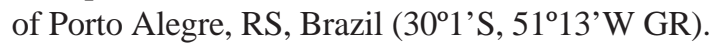
Site $\mathrm{A}$ is at Visconde Duprat street, in a private garden, and has three host plants. Site B, distant about $500 \mathrm{~m}$, is at Ivo Corseuil street, on the sidewalk, and there are at least four individuals of the host plant. Both sites have small sized plants, no taller than $2 \mathrm{~m}$, and five of the plants are less than $1 \mathrm{~m}$ tall (Mendonça \& Romanowski, 2002). Observations on other host plants close to the sites were made occasionally. From September 1995 till March 1996, scattered observations were continued on site A.

Insects found to be associated with the gallmaker or gall tissues were collected and preserved in ethanol $70^{\circ} \mathrm{GL}$. Occasionally, gall-bearing shoots were also collected and brought to the laboratory. There they were either kept in small plastic pots with wet tissue paper at the bottom or in flowerpots with soil, covered by a plastic transparent cylinder, to obtain adult gall-makers and parasitoids. Under a stereomicroscope, galls were opened to observe its contents and damage done to its tissues. Larvae of the parasitoids were also collected after opening the galls and preserved in ethanol $70^{\circ} \mathrm{GL}$.

\section{RESULTS}

\section{Predatory ants}

E. dispar galls were attacked by at least three different species of ants. The attacks can be recognised by the rupture of the gall tissues and darkening of its surface caused by the drying out of the ripped parts. Attacked galls ranged from mature to those early in the development (Mendonça, 1996). Usually, early developing galls were left totally open, with the gall chamber exposed (and no gall-maker larva). Mature galls usually borne either dry spots outside (probably mandible marks) or an orifice, indicating the ants made a tunnel and reached the gall chamber (successful predation).

In both sampling sites, predation occurred between December and May (Table 1), affecting the most numerous generations of the gall-maker. In this case predation was caused by Pseudomyrmex sp., a species with slender-bodied workers (3-4 mm long) of a brownish colour and powerful mandibles. They were very active and aggressive, and a maximum of four individuals were seen at the same time in a single plant. Predation intensity varied much from one generation to another $(13 \%$ to $41 \%$ ), and between different plants (Mendonça, 1996). 
TABLE 1

Occurrence of Pseudomyrmex sp. workers preying upon Eugeniamyia dispar galls at the sampled sites at Porto Alegre, RS, Brazil (30'1'S, 51 ${ }^{\circ} 13$ 'W), during the 93/94 and 94/95 seasons. Dashes indicate there were no galls on the plant in that month. Shaded areas indicate periods when there was no sampling on the plant "A2" on the 93/94 season and on plants "B1" and "B2" on September-October of the 93/94 season.

\begin{tabular}{|c|c|c|c|c|c|c|c|c|c|c|c|c|c|c|c|c|c|c|c|c|c|}
\hline \multirow{2}{*}{ Site } & \multirow{2}{*}{ Plant } & \multicolumn{10}{|c|}{ 93/94 } & \multicolumn{10}{|c|}{ 94/95 } \\
\hline & & Sep & Oct & Nov & Dec & Jan & Feb & Mar & Apr & May & Jun & Sep & Oct & Nov & Dec & Jan & Feb & Mar & Apr & May & Jun \\
\hline $\mathbf{A}$ & 1 & & & & $\times$ & $\times$ & $x$ & $\times$ & - & - & - & & & & & $x$ & $\times$ & $\times$ & $\times$ & $x$ & \\
\hline & 2 & & & & & & & & & & & & & & & $x$ & - & - & - & - & - \\
\hline B & 1 & & & & $x$ & $x$ & $\times$ & $\times$ & $\times$ & & & & & & & & $\times$ & & & $\times$ & - \\
\hline & 2 & & & & & & & & $x$ & - & - & & & & & & & & & - & - \\
\hline
\end{tabular}

In 1996, scattered observations revealed an ant species of the genus Pheidole attacking galls on site A. Workers of this species are 1-1.5 mm long and amber coloured. When this ant was observed attacking the galled leaves about one ant per gall could be found; thus, large numbers of workers were present (about twenty per leaf) ripping the gall tissues, but leaving only small holes on them. These ants were also tending Homoptera nymphs of an unidentified species in E. uniflora leaves nearby.

Finally, in 1995, on an E. uniflora plant 200 $\mathrm{m}$ far from the site $\mathrm{B}$, a third unidentified ant species of small $(2 \mathrm{~mm})$ black workers with a heartshaped abdomen, were also observed attacking $E$. dispar galls. These ants made round holes in the galls, and were actively entering and exiting the open galls. A few workers (2-4) could be found on each attacked galled leaf.

\section{Parasitoids}

Laboratory rearing of galls showed a high frequency (about 50\%) of them originating hymenopteran parasitoids instead of gall-makers. Almost all of the wasps thus obtained belonged to a single species of the genus Rileya (Eurytomidae), a small ( $\pm 1-2 \mathrm{~mm}$ in length) amber wasp with a dark spot on the top of the abdomen, especially visible in males. Only 6 individuals of another species of a black microhymenopteran (Chalcidoidea), as yet unidentified, were reared so far. Also, in the field, Rileya sp. adults were very common, roaming around galled leaves. These insects were observed almost throughout the year (Table 2), except for late June to September, when its host was not present or just at the beginning of the first generation. In the two years of observations, the other wasp species was observed only three times in the field, landing on galled leaves, in both sampling sites in October 1994, and once more in January 1995 in site B. Oviposition by this second species (or at least an oviposition trial) could be observed at least once.

Rileya sp. is a solitary ectoparasitoid. The eggs cannot be seen by the naked eye, but under a microscope they are transparent and slender. Only one egg is generally laid on each host. Occasionally two eggs may be found on a single host, indicating some degree of superparasitism. The first instar larva is about the size of the egg, the head wider than the rest of the body. Just after eclosion the larva starts feeding on its host, growing remarkably in body volume. Its visceral contents now appear light brown. The fully-grown larva is translucent, with a conspicuous yet not distinctly sclerotised head and minute red mandibles. The parasitoid larva, after consumption of its whole host, is always found associated to the gall chamber roof, which is the nutritive tissue of the gall (Mendonça, 1996). The last larval instar moves little, but burrows its exit tunnel from the gall chamber to the epidermis, leaving the latter intact. It then comes back to the chamber and pupates with the head towards the tunnel. As the pupa develops it becomes orange pigmented. 
TABLE 2

Occurrence of Rileya sp. adults on leaves galled by Eugeniamyia dispar at the sampled sites at Porto Alegre, RS, Brazil (30 ${ }^{\circ} 1^{\prime} S, 5^{\circ} 13$ 'W), during the 93/94 and 94/95 seasons. Dashes indicate there were no galls on the plant in that month. Shaded areas indicate periods when there was no sampling on the plant "A2" on the 93/94 season and on plants "B1" and "B2" on September-October of the 93/94 season.

\begin{tabular}{|c|c|c|c|c|c|c|c|c|c|c|c|c|c|c|c|c|c|c|c|c|c|}
\hline \multirow{2}{*}{ Site } & \multirow{2}{*}{ Plant } & Sep & Oct & Nov & Dec & Jan & Feb & Mar & Apr & May & Jun & Sep & Oct & Nov & Dec & Jan & Feb & Mar & Apr & May & Jun \\
\hline A & $\mathbf{1}$ & & & $\times$ & & $\times$ & $\times$ & $\times$ & - & - & - & & $\times$ & & & $\times$ & $\times$ & $\times$ & & $\times$ & \\
\hline & 2 & & & & & & & & & & & & & $\times$ & & $\times$ & - & - & - & - & - \\
\hline B & $\mathbf{1}$ & & & $\times$ & $\times$ & $\times$ & $\times$ & $\times$ & $\times$ & $\times$ & $\times$ & & $\times$ & $\times$ & $\times$ & $\times$ & $\times$ & $\times$ & & $\times$ & - \\
\hline & 2 & & & & & & $\times$ & $\times$ & & - & - & & & & & $\times$ & $\times$ & $\times$ & & - & - \\
\hline
\end{tabular}

At emergence the adult rips the epidermis, producing a small oval-shaped orifice, and leaves the gall. During morning field observations, recently emerged adults could be seen extending their wings under the sun, jumping from one shoot to another when disturbed. Adults were also seen copulating on E. uniflora foliage. Females oviposit on galls fully or almost fully developed, containing last instar larvae of the gall-maker. Oviposition involves the repeated introduction of the ovipositor in the gall, probably in order to reach the chamber and the larva at the correct angle. This action originates a series of small brown points side by side on the surface of the gall. Nevertheless, as many other mechanical factors can also leave marks similar to these (including ant predation trials), they can rarely be undoubtedly attributed to oviposition by Rileya sp. The female stunts the gall-maker larva with the ovipositor before placing the egg on the host (idiobiosis, sensu Askew \& Shaw, 1986). The gall-maker larva becomes swollen, so that the segments cannot be distinguished, but the thoracic spatula is still visible. Paralysis would prevent the parasitoid larva from facing behavioural resistance of the host, which is very active in its last instar (Mendonça \& Romanowski, 2002). and could smash the ectoparasitoid against the gall chamber walls, for example.

The parasitoid Rileya sp. also has its own natural enemies. During field observations, a couple of times there were encounters between predatory Pseudomyrmex sp., presumably searching for the galls, and adult parasitoids roaming around galled leaves (Table 1). At these encounters the wasp was always attacked by the ant, sometimes managing to escape or else being captured and devoured. Another time, eight adult Rileya sp. were found caught in the web of an Achaearanea hirta (Theridiidae, Araneae), spun close to an E. uniflora shoot, which bore galls recently open, where the insects supposedly came from.

Rileya sp. was found in Rio Grande do Sul and Santa Catarina states, covering the known distribution of its host - from latitudes $27^{\circ} 30^{\prime}$ and $30^{\circ}$ (Mendonça \& Romanowski, 2002).

\section{DISCUSSION}

\section{Predatory ants}

Ants have an astounding local diversity, as well as remarkable population abundance, being among the leading predators of other insects in most terrestrial habitats (Holldobler \& Wilson, 1990). Ants have a series of ecological relationships with gall-makers, as predators, mutualists (Seibert, 1993), or successori (gall occupants after the leaving of the gall-maker, e.g. Fernandes $e t$ al., 1989). The attractiveness of an immobile prey inside a soft plant tissue probably makes $E$. dispar a profitable source of food, once it is found. Additionally, as the nutritive tissue of the gall probably provides the gall-maker larva with exudates (nutritive cells are not consumed by the larvae, Mendonça, 1996), it may be possible that for a time after being open, the gall still produces liquids, which the ants could also use as food. The entering- 
exiting behaviour of the ants in respect to open galls could thus result simply from their own searching behaviour or, alternatively, from a situation of reward coming from the gall in the form of these exudates. Secreting of sugar-rich substances by galls has been reported (Mani, 1964), but usually as an external characteristic of the galls, with the gall-maker still alive inside it, perhaps conferring an additional defence against predation and/or parasitism of the galls through attraction of such predatory ants.

As noted above, the first step on using the gall depends on the probability of finding it and then on its nutritional value as food. Thus, E. dispar galls may become attractive only when they can be easily found, i.e. when the gall-maker population is large. This could explain why the ant predatory attacks on the galls concentrated in the summer months (Table 1). Also, perhaps the phenology of the ants is such that they are more active in this period. Once galls are included as food items to the ants, even if the gall-maker population decrease in numbers, they could still be searched for, and that would be why predation extended through the end of Summer (April and May, Table 1).

In respect to Pheidole sp., though, it may be more plausible to think about the presence of the ants on the plant due to the tended homopteran nymphs. The attack on the galls may be either an opportunistic use of the galls as a source of food or also an act of protection to the tended insects. It is known that tending ants on a given plant can attack other (non-tended) herbivores (Strong et al., 1984), the ones tended benefited from reduced competition for the plant resources.

Still in regard to finding the galls, another fact to be considered is the territoriality exhibited by ant species - aggressive ones defend the plants they inhabit or forage on from other species, creating an "ant mosaic" (Leston, 1978). Being a dynamic mosaic, this could be the reason why each year, each host plant had only one species of ant attacking the galls it borne. This behaviour could result in an advantage to the gall-maker, for the recorded amount of predation is probably lower than it would be if many species of ant searched each plant. The presence of adult Rileya sp. around the galled leaves and shoots could also attract the ants, at least Pseudomyrmex sp. The latter has big workers compared with Rileya sp. adults, and agile ones too, so they can also prey upon mobile insects.

\section{Parasitoids}

This study was carried out in a restricted area, although for a long period, and only two species of parasitoids could be found on E. dispar so far. Rileya sp. clearly dominates the parasitoid guild on this host. It is abundant and frequent throughout the whole period of occurrence of its host (Table 2). Contrastingly, the black parasitoid species was found only in the beginning of the season in October, and in January, before the increase in both gallmaker and Rileya sp. populations, or even before the appearance of the latter (Mendonça, 1996).

The Eurytomidae includes many species associated to insect galls (Askew \& Shaw, 1986), both as parasitoids and as gall-makers. The subfamily Rileyinae is commonly associated with gall-forming Cecidomyiidae (Boucek, 1988), and species of Rileya can be found parasitising the genus Asphondylia (Waring \& Price, 1989; Hawkins \& Goeden, 1984; Highland, 1964; Plakidas, 1982; Plakidas \& Weis, 1994). Another example of a gall-maker parasitised by Rileya is Eutreta diana (Tephritidae; Goeden, 1990) on the host plant Artemisia tridentata. Gall-makers, as endophytic hosts, usually have idiobiont parasitoids (Hawkins et al., 1990), as is the case with Rileya sp. The protection obtained from the surrounding tissues "allows" the parasitoid larva to develop outside its host, avoiding the immunological trouble of living endoparasitically (Strand, 1986). Thus, the parasitoids benefits at least from the microenvironment created by the gall, if not from other kinds of protection usually associated with them (Price et al., 1987). The parasitoid is also free from becoming specialised on a single host, and consequently it is possible that Rileya sp. has other so far unknown hosts, which would perhaps allow it to survive the winter while $E$. dispar galls cannot be found in the field.

The position of the larva of Rileya sp., found on the gall nutritive tissue when the host larva was already consumed, may be due only to the fact that the host larva itself is always in contact with this part of the gall. However, the parasitoid larva consumes the host quickly, and it may be not enough for the whole development of the former. It could be, then, that the parasitoid also benefits from the nutritive tissue exudates as an extra source of ener- 
gy. This kind of phenomenon has been reported for an Eurytomidae parasitoid (Eurytoma aciculata), which feeds on the gall tissue after its Tenthredinidae host, is completely devoured (Hanapi, 1980, apud Askew \& Shaw, 1986).

As a concluding remark, it can be said that the integration of the plant, the gall-maker and the gall clearly results in a complex interaction, generating a true ecosystem (Mani, 1964). Other species higher on the food web may also get involved in this relationship and obtain profits from it. Thus, the morphological and physiological alteration induced by the gall-maker on the plant can be beneficial to other species as well, as is the case of the exudates from the nutritive tissue. Although it cannot yet be proved that such relationships actually exist (either for ants or for Rileya sp.), the possibilities deserve future attention.

Acknowledgments — The authors would like to thank Rosângela Faria of the Departamento de Ecologia Evolutiva of UFSCar for identifying the Eurytomidae parasitoids. The ants were identified by Elena Diehl-Fleig, of the Departamento de Genética of UNISINOS to whom we are also grateful. The spider was kindly identified by Arno Lise, of the Departamento de Zoologia, PUCRS. Specimens were deposited in the entomo/aracnological collection of each University. Thanks to Miriam Becker for helpful comments and suggestions on previous drafts of this paper. This work was supported by FAPERGS and CAPES, to whom we are also thankful.

\section{REFERENCES}

ASKEW, R. R., 1980, The diversity of insect communities in leaf-mines and plant galls. J. An. Ecol., 49: 817-829.

ASKEW, R. R. \& SHAW, M. R., 1986, Parasitoid communities: their size, structure and development. pp. $225-$ 264. In: J. Waage \& D. Greathead (eds.), Insect parasitoids. Academic Press, London, UK, 389p.

BOUCEK, Z., 1988, Australasian chalcidoidea (Hymenoptera). CAB International, Wallingford, Australia, 832p.

BROWN, J. M., ABRAHAMSON, W. G., PACKER, R. A. \& WAY, P. A., 1995, The role of natural-enemy escape in a gallmaker host-plant shift. Oecologia, 104: 52-60.

CORNELL, H. V. \& HAWKINS, B. A., 1995, Survival patterns and mortality sources of herbivorous insects: some demographic trends. Am. Nat., 145: 563-593.

DARWIN, C., 1859, The origin of species. Penguin Books, London, UK, 477p.

FERNANDES, G. W., BOECLEN, W. J., MARTINS, R. P. \& CASTRO, A. G., 1989, Ants associated with a coleopterous leaf-bud gall on Xylopia aromatica (Annonaceae). Proc. Entomol. Soc. Wash., 91: 81-87.
GOEDEN, R. D., 1990, Life-history of Eutreta diana (Osten Sacken) on Artemisia tridentata Nuttall in southern California (Diptera:Tephritidae). Pan-Pac. Entomol., 66: 2432.

HANAPI, S. B., 1980, A study of insect communities associated with galls of sawflies and other insects on willows. $\mathrm{PhD}$ thesis, University of Manchester, Manchester, UK, apud R. R. Askew \& M. R. Shaw, 1986, Parasitoid communities: their size, structure and development, pp. 225264. In: J. Waage \& D. Greathead (eds.), Insect parasitoids. Academic Press, London, UK, 389p.

HARTLEY, S. E. \& LAWTON, J. H., 1992, Host-plant manipulation by gall-insects: a test of the nutrition hypothesis. J. Anim. Ecol., 61: 113-119.

HAWKINS, B. A., 1988, Do galls protect endophytic herbivores from parasitoids? A comparison of galling and nongalling Diptera. Ecol. Entom., 13: 473-477.

HAWKINS, B. A., ASKEW, R. R. \& SHAW, M. R., 1990, Influences of host feeding-niche and foodplant type on generalist and specialist parasitoids. Ecol. Entomol., 15: 275-280.

HAWKINS, B. A. \& GOEDEN, R. D., 1984, Organization of a parasitoid community associated with a complex of galls on Atriplex spp. in southern California. Ecol. Entomol., 9: 271-292.

HIGHLAND, H. A., 1964, Life-history of Asphondylia ilicicola (Diptera:Cecidomyiidae), a pest of American holly. J. Econ. Entomol., 57: 81-83.

HOLLDOBLER, B. \& WILSON, E. O., 1990, The ants. Springer-Verlag, Berlin, Germany, 732p.

LESTON, D., 1978, A neotropical ant mosaic. Ann. Entom. Soc. Am., 71: 649-653.

MAIA, V. C., MENDONÇA, M. de S., JR. \& ROMANOWSKI, H. P., 1996, Eugeniamyia dispar, n. gen., and n. sp. (Diptera, Cecidomyiidae, Lasiopteridi) associated with Eugenia uniflora L. (Myrtaceae) in Brazil. Revta. Bras. Zool., 13: 1087-1090.

MANI, M. S., 1964, Ecology of plant galls. Dr. W. Junk Publisher, The Hague, Netherlands, 434p.

MENDONÇA, M. de S., Jr., 1996, Ecologia de Eugeniamyia dispar (Diptera: Cecidomyiidae), galhador sobre Eugenia uniflora (Myrtaceae). M. Sc. Dissertation, Instituto de Biociências, Universidade Federal do Rio Grande do Sul, Porto Alegre.

MENDONÇA, M. de S., Jr. \& ROMANOWSKI, H. P., 2002, Life history of the gall-maker Eugeniamyia dispar Maia, Mendonça \& Romanowski 1996 (Diptera, Cecidomyiidae). Revta. Bras. Biol., 62(2): 277-283.

PLAKIDAS, J. D., 1982, Note on gall inhabitants of Asphondylia helianthiglobulus Osten Sacken (Diptera: Cecidomyiidae) in western Pennsylvania. J. of N. Y. Entom. Soc., 90: 2-4.

PLAKIDAS, J. D. \& WEIS, A. E., 1994, Depth associations and utilization patterns in the parasitoid guild of Asphondylia rudbeckiaeconspicua (Diptera: Cecidomyiidae). Environm. Entomol., 23: 115-121. 
PRICE, P. W., 1984, Insect ecology. Academic Press, New York, USA, 607p.

PRICE, P. W., FERNANDES, G. W. \& WARING, G. L., 1987, Adaptive nature of insect galls. Environ. Entomol., 16: $15-24$

PRICE, P. W. \& PSCHORN-WALCHER, H., 1988, Are galling insects better protected against parasitoids than exposed feeders?: a test using tenthredinid sawflies. Ecol. Entom., 13: 195-205.

SCHULTZ, B. B., 1992, Insect herbivores as potential causes of mortality and adaptation in gallforming insects. Oecologia, 90: 297-299.

SEIBERT, T. F., 1993, A nectar-secreting gall wasp and ant mutualism: selection and counter-selection shaping gall wasp phenology, fecundity and persistence. Ecol. Entomol., 18: 247-253.
STRAND, M. R., 1986, The physiological interactions of parasitoids with their hosts and their influence on reproductive strategies, pp. 97-136. In: J. Waage \& D. Greathead (eds.), Insect parasitoids. Academic Press, London, UK, $389 \mathrm{p}$.

STRONG, D., JR., LAWTON, J. \& SOUTHWOOD, R., 1984, Insects on plants. Blackwell Sci. Publ., Oxford, UK, 313p.

WARING, G. L. \& PRICE, P. W., 1989, Parasitoid pressure and the radiation of a gallforming group (Cecidomyiidae: Asphondylia spp.) on creosote bush (Larrea tridentata). Oecologia, 79: 293-299.

WEIS, A. E. \& ABRAHAMSON, W. G., 1986, Evolution of host-plant manipulation by gall-makers: ecological and genetical factors in the Solidago-Eurosta system. Am. Nat., 127: 681-695. 